\title{
Enantioselective Electrodialysis of Amino Acids with Charged Polar Side Chains through Molecularly Imprinted Polymeric Membranes Containing DIDE Derivatives
}

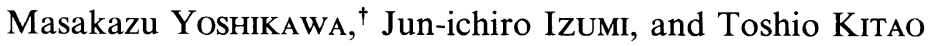 \\ Department of Polymer Science and Engineering, Kyoto Institute of Technology, \\ Matsugasaki, Sakyo-ku, Kyoto 606, Japan
}

(Received June 7, 1996)

\begin{abstract}
Molecularly imprinted polymeric membranes, bearing tetrapeptide derivative $\mathrm{H}-\mathrm{Asp}(\mathrm{OcHex})-\mathrm{Ile}-$ Asp $(\mathrm{OcHex})-\mathrm{Glu}(\mathrm{OBzl})-\mathrm{CH}_{2^{-}}$, were prepared during the membrane preparation (casting) process in the presence of print molecule Boc-L-Trp. The molecularly imprinted membranes thus obtained showed adsorption selectivity toward print molecule family, such as L-Arg, L-Lys, L-His, L-Asp, and L-Glu. The tetrapeptide derivative in the molecularly imprinted membranes preferentially recognized L-amino acid from racemic amino acids. Enantioselective electrodialysis was attained with the present membrane, and L-isomer was permeated in preference to D-isomer, while D-isomer was preferentially permeated by using concentration difference as a driving force for membrane transport. It was made clear that the optical resolution was attained by the molecularly imprinted polymeric membranes.

KEY WORDS Molecular Imprinting / Optical Resolution / Electrodialysis / Chiral Recognition / Enantioselective Permeation / Membrane / Amino Acids /
\end{abstract}

Developing novel membrane materials for optical resolution is an important and interesting subject in connection with pharmaceutical industry, food production, and so force. The optical resolution with synthetic membranes were first investigated by liquid membranes containing chiral crown ethers. ${ }^{1-4}$ From the viewpoint of the durability of liquid membrane, studies on the optical resolution with polymeric membranes have emerged. There have been pioneering reports on polymeric membranes for optical resolution, such as plasma-polymerized membranes of $d$-camphor ${ }^{5}$ and $l$ menthol, ${ }^{5,6}$ polymeric membranes having cyclodextrin moieties, ${ }^{7}$ polymeric chiral crown ethers, ${ }^{8}$ poly(amino acid) membranes having amphiphilic side chains, ${ }^{9,10}$ enantioselective ultrafiltration membrane bearing amino acid condensate, ${ }^{11}(+)$-poly $\{1$-[dimethyl(10-pinanyl)silyl]-1-propyne $\}$ membrane, ${ }^{12}$ polysulfone membranes with immobilized bovine serum albumin, ${ }^{13,14}$ sericine membrane, ${ }^{15}$ cellulose tris(3,5-dimethylphenylcarbamate) membrane, ${ }^{16}$ poly $\{\gamma$-[3-(pentamethyldisiloxyl)propyl]-L-glutamate $\}$ membrane, ${ }^{17}$ poly(methyl methacrylate) (PMMA) membranes containing (-)-oligo\{methyl(10-pinanyl)siloxane $\},{ }^{18}$ and (+)-poly $\{1$-[dimethyl(10-pinanyl)silyl]-1-propyne $\}$ membrane. ${ }^{19}$

Optically active compounds, such as amino acids, give same physicochemical properties, excepting optical activity. From this, physical stereoselectivity might be an important factor to recognize and to separate optically active compounds. All synthetic membranes for optical resolution already reported ${ }^{1-19}$ possess such chiral microenvironments in them. Oligopeptide is one of promising candidates to render chiral environment to synthetic membrane. Based on this, polystyrene resin bearing H-Asp(OcHex)-Ile-Asp(OcHex)-Glu(OBzl)$\mathrm{CH}_{2}$ - (DIDE-Resin) was adopted as a membrane material for optical resolution.

It is required to introduce chiral microenvironment into molecular recognition site, tetrapeptide derivative

\footnotetext{
† To whom correspondence should be addressed.
}

residue, in the membrane so that the membrane may show optical resolution. Molecular imprinting technique, which was first proposed by Wulff and his coworkers, ${ }^{20-22}$ might be one of the promising and practical ways to introduce chiral recognition site into synthetic polymeric membranes. Molecular imprinting technique was applied to the free-standing membrans for the transport of nucleic acid component. ${ }^{23}$ However, Wulff's molecular imprinting technique itself is not applicable to our case. So we prepared the membrane from the polystyrene resin bearing DIDE derivative (DIDE-Resin), which was expected to render chiral microenvironment, by the alternative molecular imprinting method, membrane preparation with simultaneous molecular imprinting previously reported. ${ }^{24,25}$

In the present article, chiral recognition and enantioselective electrodialysis of racemic amino acids with charged polar side chains by using molecularly imprinted polymeric membrane bearing tetrapeptide derivative, $\mathrm{H}-\mathrm{Asp}(\mathrm{OcHex})-\mathrm{Ile}-\mathrm{Asp}(\mathrm{OcHex})-\mathrm{Glu}(\mathrm{OBzl})-\mathrm{CH}_{2^{-}}$, are described.

\section{EXPERIMENTAL}

\section{Materials}

Protected amino acids, Boc-L-Glu(OBzl), Boc-LAsp(OcHex), and Boc-L-Ile, were kindly provided by Kyowa Hakko Kogyo Co., Ltd. Chloromethylated polystyrene resin (Cl-Resin) (1\% divinylbenzene), which $\mathrm{Cl}$ content was $0.78 \mathrm{meq}^{-1}$, and dicyclohexylcarbodiimide (DCC) were purchased from Peptide Institute, Inc., Osaka, Japan and used without further purification. Dichloromethane, ${ }^{26}$ trifluoroacetic acid (TFA), ${ }^{26}$ diisopropylethylamine (DIEA), ${ }^{27}$ and 2-propanol ${ }^{26}$ were purified by the usual methods. The copolymer from acrylonitrile and styrene (AS), which weight fraction of acrylonitrile unit was 0.33 , was kindly supplied by Ube Cycon, Ltd. D-Arg, L-Arg, D-Lys, L-Lys, D-His, L-His, D-Asp, L-Asp, D-Glu, L-Glu, Boc-L-Trp, sodium azide, and ethanol were used without purification. Distilled 
water was employed.

\section{Preparation of Membrane Materials}

The membrane materials were prepared by Merrifield's technique of solid phase peptide synthesis. ${ }^{28,29}$ Boc-L$\mathrm{Glu}(\mathrm{OBzl})-\mathrm{OCH}_{2} \mathrm{C}_{6} \mathrm{H}_{4}$-resin was prepared from $1.000 \mathrm{~g}$ $\left(2.96 \times 10^{-3} \mathrm{~mol}\right)$ of Boc-L-Glu(OBzl $)$ and $0.726 \mathrm{~g}$ $\left(5.66 \times 10^{-4}\right.$ unit mol of chloromethyl moiety) of chloromethylated polystyrene resin ( $1 \%$ divinylbenzene).$^{30}$

Boc-L-Glu(OBzl)- $\mathrm{OCH}_{2} \mathrm{C}_{6} \mathrm{H}_{4}$-resin $(0.878 \mathrm{~g}, 5.05 \times$ $10^{-4}$ unit mol of Boc-L-Glu(OBzl) moiety) was placed in a manual reactor similar to one reported ${ }^{31}$ and carried through the schedules ${ }^{32}$ shown in Table I. The "pre-mix" reaction mixture used in all other couplings (Table I) was prepared as follows: $3.15 \mathrm{mmol}$ of Boc-L-amino acid in $9 \mathrm{~cm}^{3}$ of $\mathrm{CH}_{2} \mathrm{Cl}_{2}$ was cooled at $0^{\circ} \mathrm{C}$ and mixed with $326 \mathrm{mg}(1.58 \mathrm{mmol})$ of $\mathrm{DCC}$ in $\mathrm{CH}_{2} \mathrm{Cl}_{2}\left(6 \mathrm{~cm}^{3}\right)$. After the mixture was stirred for $30 \mathrm{~min}$ at $0^{\circ} \mathrm{C}$, the precipitate was filtered at ambient temperature and washed with $2 \mathrm{~cm}^{3}$ of $\mathrm{CH}_{2} \mathrm{Cl}_{2}$. The combined filtrate and washings were added immediately to the resin manually. The completeness of coupling was monitored by qualitative ninhydrin tests. ${ }^{33}$ Acylation was judged complete in coupling of Boc-L-Asp(OcHex) after two cycles. In case of Boc-L-Ile, three cycles of the coupling reaction were carried out to be judged complete. Following the schedule mentioned above, the polystyrene resin bearing tetrapeptide derivative, Boc-Asp(OcHex)-Ile-Asp(OcHex)-Glu(OBzl)- $\mathrm{CH}_{2}-$ (Boc-DIDE-Resin) was obtained. The polystyrene resin bearing $\mathrm{H}-\mathrm{Asp}(\mathrm{OcHex})-\mathrm{Ile}-\mathrm{Asp}(\mathrm{O}-$ cHex)-Glu(OBzl)- $\mathrm{CH}_{2}-$ (DIDE-Resin) was derived from Boc-DIDE-Resin by treatment with trifluoroacetic acid in dichloromethane. ${ }^{32}$

From the hydrolysis of polystyrene resin thus obtained and the derivatization with phenylisothiocyanate ${ }^{34}$ or (dimethylamino)azobenzenesulfonyl chloride, ${ }^{35}$ the concentration of tetrapeptide derivative thus introduced into chloromethylated polystyrene resin was estimated to be $0.28 \mathrm{mmol} \mathrm{g}^{-1}$ DIDE-Resin.

\section{Preparation of Molecularly Imprinted Polymeric Mem- branes}

The polymeric membrane studied in the present paper was prepared from tetrahydrofuran solution. Copolymer of acrylonitrile and styrene (AS), which weight fraction of acrylonitrile unit was 0.33 , was adopted as a membrane

Table I. Schedule for performed anhydride coupling

\begin{tabular}{|c|c|c|}
\hline \multirow{2}{*}{ Step } & \multirow{2}{*}{ Operation and reagent ${ }^{a}$} & \multirow{2}{*}{$\frac{\text { Mixing time }}{\min }$} \\
\hline & & \\
\hline 1 & $\mathrm{CH}_{2} \mathrm{Cl}_{2}, 50 \mathrm{~cm}^{3}$ ( 5 times $)$ & 1 \\
\hline 2 & $20 \% \mathrm{TFA} / \mathrm{CH}_{2} \mathrm{Cl}_{2}, 40 \mathrm{~cm}^{3}$ (once) & 2 \\
\hline 3 & $20 \%$ TFA $/ \mathrm{CH}_{2} \mathrm{Cl}_{2}, 50 \mathrm{~cm}^{3}$ (once) & 20 \\
\hline 4 & $\mathrm{CH}_{2} \mathrm{Cl}_{2}, 50 \mathrm{~cm}^{3}$ (5 times) & 1 \\
\hline 5 & $5 \%$ DIEA $/ \mathrm{CH}_{2} \mathrm{Cl}_{2}, 40 \mathrm{~cm}^{3}$ (3 times) & 2 \\
\hline 6 & $\mathrm{CH}_{2} \mathrm{Cl}_{2}, 50 \mathrm{~cm}^{3}$ (5 times) & 1 \\
\hline 7 & "Pre-mix" reaction mixture (once) & 90 \\
\hline 8 & $0.5 \mathrm{~mol} \mathrm{dm}{ }^{-3}$ DIEA $/ \mathrm{CH}_{2} \mathrm{Cl}_{2}, 1 \mathrm{~cm}^{3}$ (once) & 15 \\
\hline 9 & $\mathrm{CH}_{2} \mathrm{Cl}_{2}, 50 \mathrm{~cm}^{3}$ (3 times) & 2 \\
\hline 10 & $2-\mathrm{PrOH}, 40 \mathrm{~cm}^{3}$ (3 times) & 2 \\
\hline 11 & Repeat steps $4-10$ & \\
\hline
\end{tabular}

${ }^{\text {a }}$ Percentages express vol/vol ratios. matrix because DIDE-Resin does not form free-standing membrane. Boc-L-Trp was adopted as a print molecule.

The molecularly imprinted polymeric membrane was prepared from DIDE-Resin and AS, which mole ratio of print molecule to DIDE derivative was fixed to be 3 : a $3.6 \mathrm{mg}$ of print molecule Boc-L-Trp, which amount being three times of DIDE derivatives in the resin, was dissolved in a $2 \mathrm{~cm}^{3}$ of tetrahydrofuran (THF) with a 10 $\mathrm{mg}$ of DIDE-Resin. And then a $190 \mathrm{mg}$ of AS was dissolved in the previous THF solution. The THF solution thus prepared was poured into a flat laboratory dish (8.9 cm-diameter) and the solvent allowed to evaporate at ambient temperature for $24 \mathrm{~h}$. The obtained membrane was dried at $50^{\circ} \mathrm{C}$ for additional $2 \mathrm{~h}$. After drying, the print molecule was removed from the resultant membranes by known large volume of methanol till the print molecule could be hardly detected in methanol by UV analysis. In this case, it was found that approximately $93 \%$ of added print molecule was recovered from the membrane. Thickness of the membranes thus obtained was $140-150 \mu \mathrm{m}$.

The control membrane was prepared from AS and DIDE-Resin without print molecule Boc-L-Trp. Thickness of the control membrane was $140 \mu \mathrm{m}$.

\section{Adsorption of Racemic Mixtures to the Membranes}

The molecularly imprinted polymeric membranes from DIDE-Resin or the control membranes were immersed in the racemic compounds solution, which was the same mixtures studied in the enantioselective permeation, that is, a $50 \mathrm{vol} \%$ aqueous ethanol solution of racemic amino acids, which concentrations being $1.0 \mathrm{mmol} \mathrm{dm}^{-3}$, and the mixture was allowed to be equilibrated at $40^{\circ} \mathrm{C}$ during $216 \mathrm{~h}$. Aliquots of the solution at the initial stage and after $216 \mathrm{~h}$ were used for quantitative estimation by HPLC (JASCO PU 980) equipped with a UV detector (JASCO UV 970) by using a CROWNPAK CR(+) column $(250 \times 4.0$ (i.d.) $\mathrm{mm})$ (Daicel Chemical Ind., Ltd.) and aqueous perchloric acid solution as eluent.

The amount of amino acid in the supernatant subtracted from the amount initially in the solution gave the amount of amino acid adsorbed by the membrane.

Adsorption selectivity $S_{\mathrm{A}(i / j)}$ is defined as

$$
S_{\mathrm{A}(i / j)}=\left((\mathrm{AA})_{i} /(\mathrm{AA})_{j}\right) /\left(C_{i} / C_{j}\right)
$$

where $(\mathrm{AA})_{i}$ and $C_{i}$ are the amount of amino acid adsorbed in the membrane and the concentration in the solution after equilibrium was reached, respectively.

\section{Enantioselective Permeation of Racemic Mixtures}

The membrane, which effective membrane area was $3.0 \mathrm{~cm}^{2}$, was fixed tightly with Parafilm between two chambers of a permeation cell. The volume of each chamber was $40 \mathrm{~cm}^{3}$. A $50 \mathrm{vol} \%$ aqueous ethanol solution of racemic amino acids was placed in the left-

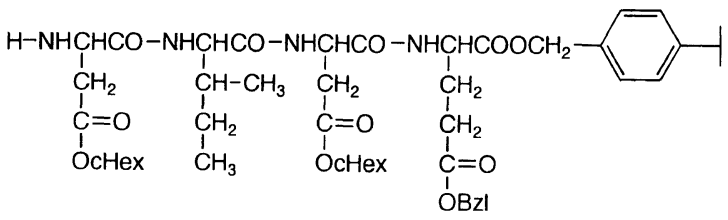

DIDE-Resin 
hand side chamber ( $\mathrm{L}$ side) and a $50 \mathrm{vol} \%$ aqueous ethanol solution in the right-hand side chamber ( $\mathrm{R}$ side). Each concentration of racemic amino acid was fixed to be $1.0 \mathrm{mmol} \mathrm{dm}^{-3}$. In both chambers, $0.02 \mathrm{wt} \%$ of sodium azide was added as a fungicide. All experiments were done at $40^{\circ} \mathrm{C}$ with stirring.

Aliquot was drawn from $\mathrm{R}$ side at each sampling time. The amounts of $\mathrm{D}$ - and $\mathrm{L}$-isomers that permeated through the membrane were estimated on an HPLC instrument described above.

The permeability coefficient, $P\left(\mathrm{~cm}^{2} \mathrm{~h}^{-1}\right)$, is defined as

$$
P=\mathrm{Q} \cdot \delta / \Delta C \cdot A \cdot t
$$

where $Q$ (mol) is the amount of permeated amino acid, $\delta(\mathrm{cm})$ is a thickness of membrane, $\Delta C\left(\mathrm{~mol} \mathrm{~cm}{ }^{-3}\right)$ is the difference in concentration of amino acid between the compartment $L$ and $R, A\left(\mathrm{~cm}^{2}\right)$ is an effective membrane area of membrane, and $t(h)$ is time.

The flux value, $J\left(\mathrm{~mol} \mathrm{~cm} \mathrm{~cm}^{-2} \mathrm{~h}^{-1}\right)$, is defined as

$$
J=Q / A \cdot t=P \cdot \Delta C / \delta
$$

The separation factor $\alpha_{i / j}$ is defined as the flux ratio $J_{i} / J_{j}$ divided by the concentration ratio $C_{i} / C_{j}$ in the feed side.

$$
\alpha_{i / j}=\left(J_{i} / J_{j}\right) /\left(C_{i} / C_{j}\right)=P_{i} / P_{j}
$$

\section{Electrodialysis}

A 50 vol\% aqueous ethanol solution of racemic amino acids was placed in the both chambers of the permeation cell. Each concentration of racemic amino acid was fixed to be $1.0 \mathrm{mmol} \mathrm{dm}^{-3}$. The electrodialysis was carried out with a prescribed applied voltage between platinum black electrodes $(10 \mathrm{~mm}$ square; distance between the electrodes, $65 \mathrm{~mm}$ ) at $40^{\circ} \mathrm{C}$ with stirring. Aliquot was drawn from permeate side at each sampling time. The amounts of D- and L-isomers that permeated through the membrane were estimated on an HPLC instrument described above.

\section{RESULTS AND DISCUSSION}

\section{Adsorption Selectivity of Racemic Amino Acids}

In Table II, amounts of amino acids adsorbed in the molecularly imprinted membranes and adsorption selectivities for the imprinted membranes are summarized.

Table II. Adsorption of amino acids in molecularly imprinted polymeric membranes ${ }^{\mathbf{a}}$

\begin{tabular}{cccc}
\hline Substrate & $10^{6}(\mathrm{AA})_{\mathrm{mem}} / \mathrm{mol}$ & $(\mathrm{AA})_{\mathrm{mem}} /(\mathrm{DIDE})$ & $S_{\mathrm{A}(\mathrm{L} / \mathrm{D})}$ \\
\hline L-Arg & $2.00 \pm 0.04$ & 5.7 & 1.3 \\
D-Arg & $1.51 \pm 0.04$ & 4.3 & \\
L-Lys & $1.30 \pm 0.04$ & 3.7 & 1.1 \\
D-Lys & $1.16 \pm 0.04$ & 3.3 & \\
L-His & $1.12 \pm 0.04$ & 3.2 & 1.3 \\
D-His & $0.84 \pm 0.05$ & 2.4 & 1.2 \\
L-Asp & $1.75 \pm 0.05$ & 5.0 & 1.2 \\
D-Asp & $1.47 \pm 0.03$ & 4.1 & \\
L-Glu & $1.93 \pm 0.04$ & 5.5 & \\
D-Glu & $1.68 \pm 0.04$ & 4.8 &
\end{tabular}

a The mole ratio of print molecule, Boc-L-Trp, to DIDE derivative in the membrane preparation process was fixed to be 3 .
The results of control experiments, in other words, the adsorption of amino acids in the control membrane, which was prepared from DIDE-Resin and AS without print moleclue, are summarized in Table III. From the data summarized in Tables II and III, following two matters are derived: (1) Non specific adsorption onto the membrane surface was negligible. (2) The composition and concentration of racemic amino acid solution during experiments were scarcely changed. As for the adsorbed amounts, they are given not only in absolute values but also in relative ones, which were converted to those of DIDE derivative basis for convenience of the following discussion. All racemic amino acids in the present study, each L-isomer was incorporated into the Boc-L-Trp imprinted membrane in preference to corresponding $\mathrm{D}$-isomer like selective adsorption of racemic tryptophans $^{24}$ or that of racemic $N$ - $\alpha$-acetyltryptophans. ${ }^{25}$ The surplus adsorbed L-isomer ranged from 0.4 to 1.4 DIDE derivative. It is hard to relate the adsorption phenomena to other natures such as net charges of these amino acids under the experimental conditions as given in Table IV, dimensions, ${ }^{36}$ and hydrophobicity ${ }^{37-40}$ (or hydro-

Table III. Adsorption of amino acids in the control membrane

\begin{tabular}{ccc}
\hline Substrate & $10^{8}(\mathrm{AA})_{\mathrm{mem}} / \mathrm{mol}$ & $\mathrm{S}_{\mathrm{A}(\mathrm{L} / \mathbf{D})}$ \\
\hline L-Glu & $0.2 \pm 1.0$ & 1.0 \\
D-Glu & $0.2 \pm 1.1$ & \\
L-Asp & $0.2 \pm 1.0$ & 1.0 \\
D-Asp & $0.2 \pm 1.0$ & \\
L-Lys & $0.2 \pm 1.0$ & 1.0 \\
D-Lys & $0.2 \pm 0.9$ & \\
L-Arg & $0.2 \pm 1.2$ & 1.0 \\
D-Arg & $0.2 \pm 1.1$ & \\
L-His & $0.2 \pm 1.1$ & \\
D-His & $0.2 \pm 1.3$ &
\end{tabular}

Table IV. $\mathrm{pH}$ values and net charges for amino acids under the experimental conditions

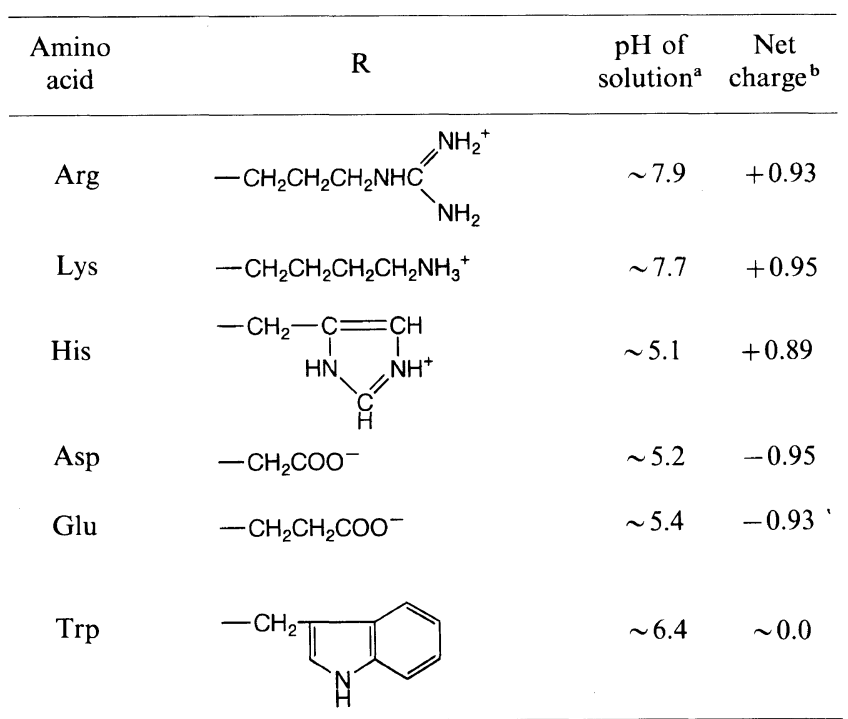

${ }^{a}$ Racemic amino acids were dissolved in a $50 \mathrm{vol} \%$ aqueous ethanol solution. Each concentration of racemic amino acid was fixed to be $1.0 \mathrm{mmol} \mathrm{dm}^{-3}$. ${ }^{\mathrm{b}} \mathrm{p} K_{\mathrm{a}}$ values adopted for calculation of net charge were cited from ref. 36 .

$$
{ }^{+} \mathrm{H}_{3} \mathrm{~N}-\underset{\mathrm{R}}{\mathrm{C}} \mathrm{H}-\mathrm{COO}^{-}
$$


philicity) of side groups of these amino acids. The adosrption selectivity of these hydrophilic amino acids were lower than that of racemic $N$ - $\alpha$-acetyltryptophans ${ }^{25}$ giving 1.8. The amounts of the hydrophilic amino acids adsorbed in the membrane are higher than $N$ - $\alpha$-acetyltryptophan and (AA) $)_{\text {mem }} /(\mathrm{DIDE})$ values for $N-\alpha$ acetyl-D-tryptophan and $N$ - $\alpha$-acetyl-L-tryptophan were determined to be 1.40 and 2.50 , respectively. From this, it can be deduced that more nonspecific interaction between present hydrophilic amino acids and the imprinted membrane was formed compared with that between $N$ - $\alpha$-acetyltryptophans and the membrane.

Through the adsorption experiments, it was made clear that the recognition site DIDE derivative, which was molecularly imprinted by the print molecule, was effective in discriminating L-amino acid from D-isomer and this ability of discrimination was effective to any amino acids.

\section{Enantioselective Permeation of Racemic Amino Acids by \\ Using Concentration Difference as a Driving Force}

Figure 1 shows the time-transport curves of racemic amino acid solutions of Arg through the Boc-L-Trp imprinted polymeric membranes. Against the adsorption selectivities, D-Arg was permeated in preference to $\mathrm{L}$ Arg. Other racemic amino acid solutions, such as, Lys, His, Asp, and Glu, D-isomers were also permeated in preference to L-isomers. The enantioselective permeation data are summarized in Table V. The fact that the permselectivity was found to be opposed to the adsorption selectivity might be due to the suppression of permeability of L-isomers by the relatively high affinity to the membrane compared with the affinity between D-isomers and the membrane as reported by enantioselective permeation. ${ }^{5,7,8,11,17}$

\section{Electrodialysis}

When their concentration difference was used as a driving force for the enantioselective permeation of racemic amino acids, the permeability of one isomer, which is incorporated into the membrane in preference to the other isomer, had a tendency to be suppressed by the relatively high affinity toward the membrane. It is an

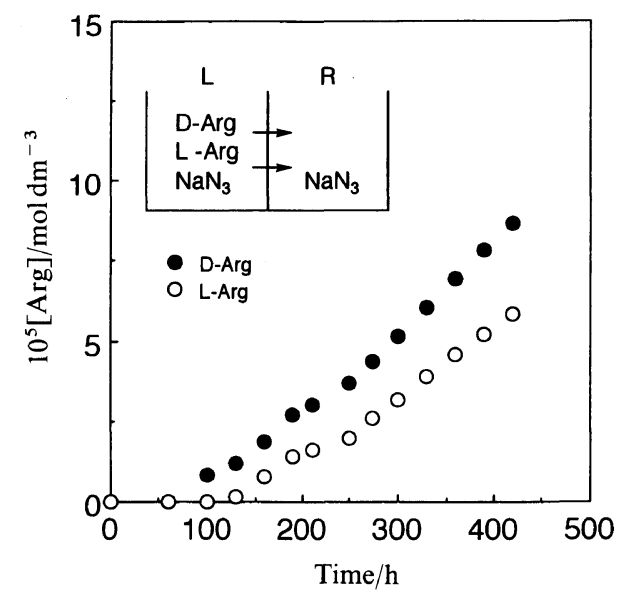

Figure 1. Time-transport curves of D- and L-Arg through molecularly imprinted polymeric membrane. (The mole ratio of print molecule, Boc-L-Trp, to DIDE derivative in the membrane preparation process was fixed to be $3 ;[\mathrm{D}-\mathrm{Arg}]_{0}=9.94 \times 10^{-4} \mathrm{~mol} \mathrm{dm}^{-3} ;[\mathrm{L}-\mathrm{Arg}]_{0}=9.90 \times$ $10^{-4} \mathrm{~mol} \mathrm{dm}^{-3} ;\left[\mathrm{NaN}_{3}\right]_{0}=2.77 \times 10^{-3} \mathrm{~mol} \mathrm{dm}^{-3}$.) interesting and important subject to permeate the isomer, which is preferentially adsorbed in the membrane, in preference to the other one, in other words, to construct the membrane transport system, reflecting adsorption selectivity. Electrodialysis, which uses potential difference as a driving force for permeation, is one of promising methods to attain such a membrane transport system, directly reflecting adsorption selectivity of Boc-L-Trp imprinted polymeric membranes from DIDE-Resin and AS. Based on this idea, electrodialysis of racemic amino acids were investigated.

Amino acids with nonpolar side chains such as Ala and so force, and those with uncharged polar side chains such as Ser and so on are not suitable for the substrates of electrodialysis, because their net charges under the present experimental conditions are calculated to be approximately null as shown in Table IV, that is, these amino acids are assumed to be zwitter ions to give, on the whole, neutral forms. ${ }^{36}$ On the other hand, amino acids with charged polar side chains, such as Lys, Arg, and His, bearing basic amino acids, and Asp and Glu, having acidic side chains, are thought to be suitable for the substrates of electrodialysis, since their net charges are estimated to be around +0.9 or -0.9 as summarized in Table IV. ${ }^{36}$ From this, electrodialysis of these five kinds of amino acids with charged polar side chains were studied.

The time transport curves of racemic Arg mixtures at the potential difference of $2.5 \mathrm{~V}$ is shown in Figure 2 as an example. Arg was charged positively under the present experimental condition and hence Arg was transported to the cathode like electrodialysis of Lys and His. In Figure 2, L-Arg was transported in preference to D-Arg as expected and permselectivity $\alpha_{\mathbf{L} / \mathbf{D}}$ was calculated to be 1.3 , which is equal to adsorption selectivity $S_{\mathrm{A}(\mathrm{L} / \mathrm{D})}$. By applying electrodialysis to the present study, enantioselective permeation system toward L-amino acid was able to be constructed. Glu and Asp were transported conversely, namely, to the anode. In all electrodialysis experiments, concentrations of $\mathrm{D}$ - and L-isomers increased linearly with time without time lag as shown in Figure 2.

It can be expected that membrane performance might be dependent on the maginutude of driving force, potential difference. Next, dependence of electrodialysis

Table V. Results of enantioselective permeation ${ }^{\mathrm{a}}$

\begin{tabular}{|c|c|c|c|c|}
\hline \multirow[t]{2}{*}{ Permeant } & \multirow{2}{*}{ 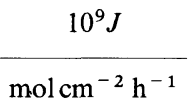 } & \multirow{2}{*}{$\frac{10^{4} P}{\mathrm{~cm}^{2} \mathrm{~h}^{-1}}$} & \multirow{2}{*}{$\left(=\begin{array}{c}\alpha_{\mathrm{D} / \mathrm{L}} \\
\left.P_{\mathrm{D}} / P_{\mathrm{L}}\right)\end{array}\right.$} & \multirow{2}{*}{$\begin{array}{c}S_{\mathrm{A}(\mathrm{D} / \mathrm{L})} \\
\left(=1 / S_{\mathrm{A}(\mathrm{L} / \mathrm{D})}\right)\end{array}$} \\
\hline & & & & \\
\hline L-Arg & 3.0 & 0.42 & 1.3 & 0.75 \\
\hline D-Arg & 3.9 & 0.55 & & \\
\hline L-Lys & 3.2 & 0.45 & 1.3 & 0.89 \\
\hline D-Lys & 4.1 & 0.57 & & \\
\hline L-His & 3.1 & 0.43 & 1.4 & 0.75 \\
\hline D-His & 4.3 & 0.60 & & \\
\hline L-Asp & 4.8 & 0.67 & 1.2 & 0.82 \\
\hline D-Asp & 5.9 & 0.83 & & \\
\hline L-Glu & 3.3 & 0.46 & 1.3 & 0.83 \\
\hline D-Glu & 4.4 & 0.61 & & \\
\hline
\end{tabular}

a The mole ratio of print molecule, Boc-L-Trp, to DIDE derivative in the membrane preparation process was fixed to be 3 . 
on potential difference was investigated and the results are shown in Figure 3. In each racemic amino acid, over the threshold potential difference separation factor reached unity and no enantioselective electrodialysis was observed. Below such a threshold potential difference, separation factor toward $\mathrm{L}$-isomer was increased to reach some value, which was equal to adsorption selectivity as can be seen in Figure 3. The optimum potential difference for electrodialysis of each amino acid, in which permselectivity was equal to adsorption selectivity, is summarized in Table VI.

In each enantioselective electrodialysis, the total flux was directly proportional to potential difference. As an example, the relationship between the total flux for Arg and potential difference is given in Figure 4.

Electrodialysis was found to be a suitable membrane transport system for racemic isomers, which reflects its adsorption selectivity between the membrane and permeant. This is considered as follows: in the case that $1.0 \mathrm{mmol} \mathrm{dm}^{-3}$ concentration difference was adopted as

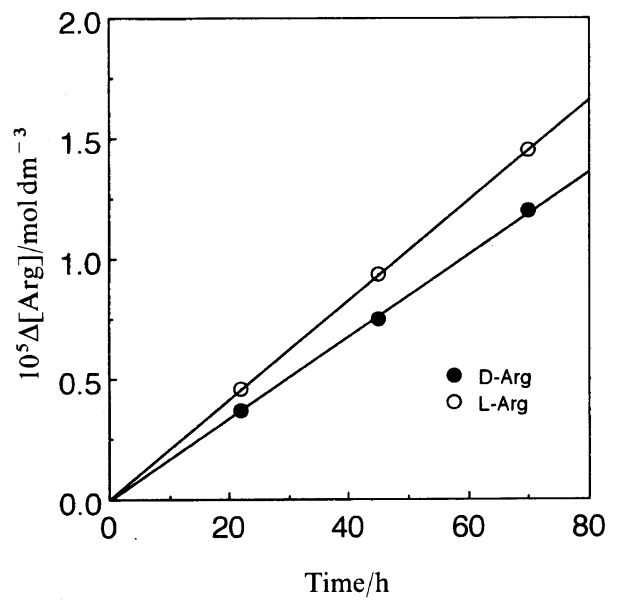

Figure 2. Time-transport curves of D- and L-Arg by electrodialysis at $\Delta \mathrm{E}=2.5 \mathrm{~V}$ through molecularly imprinted polymeric membrane. (The mole ratio of print molecule, Boc-L-Trp, to DIDE derivative in the membrane preparation process was fixed to be 3 ; $[\mathrm{D}-\mathrm{Arg}]_{0}=$ $9.94 \times 10^{-4} \mathrm{~mol} \mathrm{dm}^{-3} ;[\mathrm{L}-\mathrm{Arg}]_{0}=9.90 \times 10^{-4} \mathrm{~mol} \mathrm{dm}^{-3}$.) a driving force for membrane transport, permeation of L-isomer through the membrane was suppressed by the relatively high affinity between L-isomer and the membrane as previously described. As a result, D-isomer was permeated in preference to L-isomer, even though L-isomer was adsorbed selectively compared with corresponding $\mathrm{D}$-isomer. On the other hand, in electrodialysis, additional driving force for permeation was supplied as a form of potential difference to the membrane permeation. As a result optimum potential difference can make it possible to attain enantioselective permeation of L-isomer. However, relatively high potential difference was too much for enantioselective permeation to reflect adsorption selectivity and, as a result, permselectivity was hardly observed and $\alpha_{\mathbf{L} / \mathbf{D}}$ reached to unity.

\section{CONCLUSION}

Molecularly imprinted polymeric membranes, bearing tetrapeptide derivative, was prepared during the membrane preparation (casting) process in the presence

Table VI. Results of enantioselective electrodialysis ${ }^{a}$

\begin{tabular}{|c|c|c|c|c|}
\hline \multirow{2}{*}{$\Delta E / V$} & \multirow{2}{*}{ Permeant } & \multirow{2}{*}{ 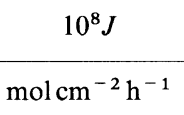 } & \multirow{2}{*}{$\alpha_{\mathrm{L} / \mathrm{D}}$} & \multirow{2}{*}{$S_{\mathrm{A}(\mathrm{L} / \mathrm{D})}$} \\
\hline & & & & \\
\hline 2.5 & $\begin{array}{l}\text { L-Arg } \\
\text { D-Arg }\end{array}$ & $\begin{array}{l}0.29 \\
0.23\end{array}$ & 1.3 & 1.3 \\
\hline 5.0 & $\begin{array}{l}\text { L-Lys } \\
\text { D-Lys }\end{array}$ & $\begin{array}{l}0.63 \\
0.58\end{array}$ & 1.1 & 1.1 \\
\hline 2.5 & $\begin{array}{l}\mathrm{L}-\mathrm{His} \\
\mathrm{D}-\mathrm{His}\end{array}$ & $\begin{array}{l}0.18 \\
0.14\end{array}$ & 1.3 & 1.3 \\
\hline 2.5 & $\begin{array}{l}\text { L-Asp } \\
\text { D-Asp }\end{array}$ & $\begin{array}{l}0.47 \\
0.40\end{array}$ & 1.2 & 1.2 \\
\hline 2.5 & $\begin{array}{l}\text { L-Glu } \\
\text { D-Glu }\end{array}$ & $\begin{array}{l}0.43 \\
0.37\end{array}$ & 1.2 & 1.2 \\
\hline
\end{tabular}

a The mole ratio of print molecule, Boc-L-Trp, to DIDE derivative in the membrane preparation process was fixed to be 3 .
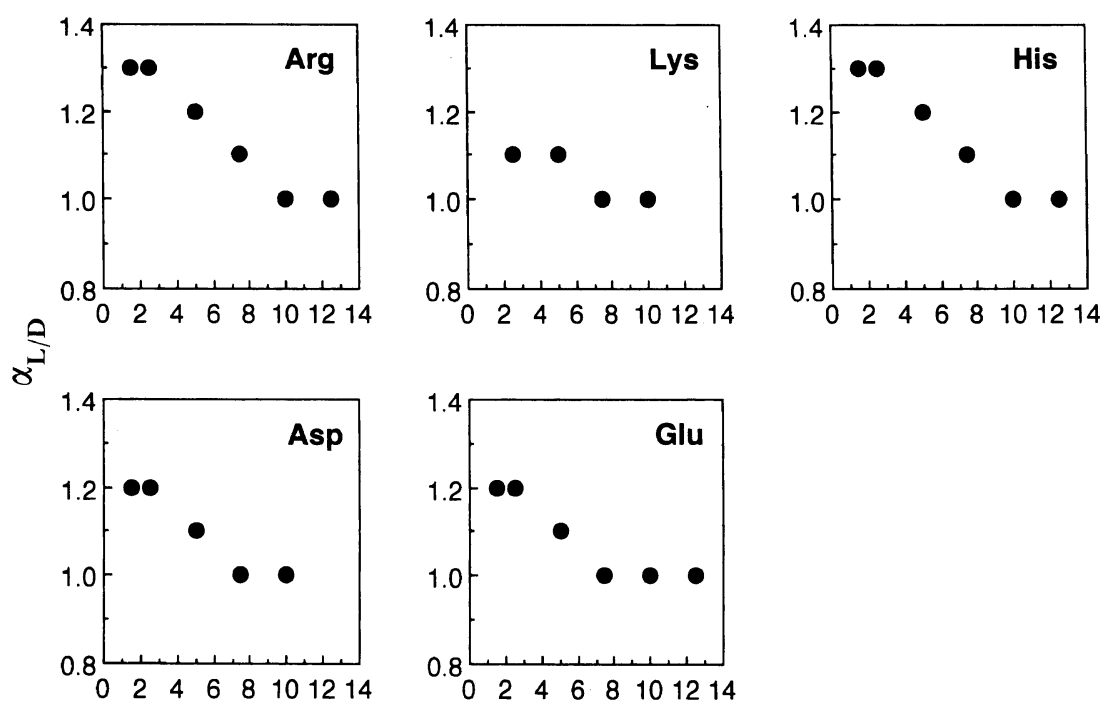

$\Delta \mathrm{E} / \mathrm{V}$

Figure 3. Influence of the difference in applied potential on enantioselective electrodialysis of amino acids. (The mole ratio of print molecule, Boc-L-Trp, to DIDE derivative in the membrane preparation process was fixed to be 3 ; $[\mathrm{D}-\mathrm{AA}]_{0} \simeq[\mathrm{L}-\mathrm{AA}]_{0} \simeq 1.00 \times 10^{-3} \mathrm{~mol} \mathrm{dm}^{-3}$.) 


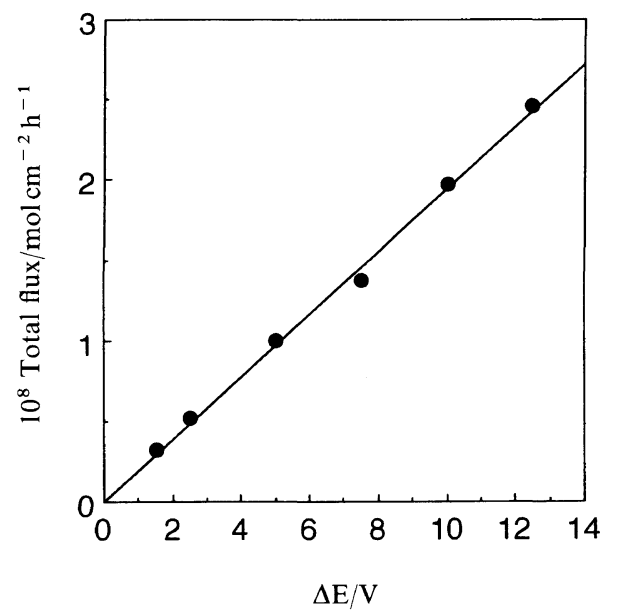

Figure 4. Influence of the difference in applied potential on total flux of Arg. (The mole ratio of print molecule, Boc-L-Trp, to DIDE derivative in the membrane preparation process was fixed to be 3 ; $[\mathrm{D}-\mathrm{Arg}]_{0} \simeq[\mathrm{L}-\mathrm{Arg}]_{0} \simeq 1.00 \times 10^{-3} \mathrm{~mol} \mathrm{dm}^{-3}$.)

of print molecule. The Boc-L-Trp imprinted polymeric membranes thus obtained showed adsorption selectivity toward print molecule family, such as L-Arg, L-Lys, L-His, L-Asp, and L-Glu. The tetrapeptide derivative in the molecularly imprinted polymeric membranes discriminated L-amino acid from D-isomer, that is, showed L-specificity. Enantioselective electrodialysis was attained with the present membrane, and L-isomer was preferentially permeated, while D-isomer was permeated in preference to L-isomer by using concentration difference as a driving force for membrane transport. Electrodialysis of racemic amino acid showed possibility that permselectivity directly reflects its adsorption selectivity. The present study suggests that the molecularly imprinted polymeric membranes has potential to attain the optical resolution of amino acids.

Acknowledgment. The present work was partly supported by the Sumitomo Foundation (to MY), which is gratefully acknowledged.

\section{REFERENCES}

1. M. Newcomb, R. C. Helgeson, and D. J. Cram, J. Am. Chem. Soc., 96, 7367 (1974).

2. M. Newcomb, J. L. Toner, R. C. Helgeson, and D. J. Cram, J. Am. Chem. Soc., 101, 4941 (1979).

3. T. Yamaguchi, K. Nishimura, T. Shinbo, and M. Sugiura, Chem. Lett., 1549 (1985).

4. H. Kikuchi, J. Hattori, Y. Mori, and T. Kajiyama, Kagaku Kogaku Ronbunshu, 15, 617 (1989).

5. Y. Osada, F. Ohta, A. Mizumoto, M. Takase, and Y. Kurimura,
Nippon Kagaku Kaishi, 866 (1986).

6. S. Tone, T. Masawaki, and T. Hamada, J. Membrane Sci., 103, 57 (1995).

7. K. Ishihara, N. Suzuki, and K. Matsui, Nippon Kagaku Kaishi, 446 (1987).

8. T. Kakuchi, T. Takaoka, and K. Yokota, Polym. J., 22, 199 (1990).

9. A. Maruyama, N. Adachi, T. Takatsuki, M. Torii, K. Sanui, and N. Ogata, Macromolecules, 23, 2748 (1990).

10. A. Maruyama, N. Adachi, T. Takatsuki, K. Sanui, and N. Ogata, Nippon Kagaku Kaishi, 1178 (1990).

11. T. Masawaki, M. Sasai, and S. Tone, J. Chem. Eng. Jpn., 25, 33 (1992).

12. T. Aoki, K. Shinohara, and E. Oikawa, Makromol. Chem., Rapid Commun., 13, 565 (1992).

13. A. Higuchi, Y. Ishida, and T. Nakagawa, Desalination, 90, 127 (1993).

14. A. Higuchi, M. Hara, T. Horiuchi, and T. Nakagawa, J. Membrane Sci., 93, 157 (1994).

15. H. Yamada, N. Fuwa, M. Nomura, M. Yoshikawa, and S Kunugi, Maku (Membrane), 18, 301 (1993).

16. E. Yashima, J. Noguchi, and Y. Okamoto, J. Appl. Polym. Sci., 54, 1087 (1994).

17. T. Aoki, S. Tomizawa, and E. Oikawa, J. Membrane Sci., 99, 117 (1995).

18. T. Aoki, A. Maruyama, K. Shinohara, and E. Oikawa, Polym. J., 27, 547 (1995).

19. K. Shinohara, T. Aoki, and E. Oikawa, Polymer, 36, 2403 (1995).

20. G. Wulff and A. Sarhan, Angew. Chem. Int. Ed. Engl., 11, 341 (1972).

21. G. Wulff, A. Sarhan, and K. Zabrocki, Tetrahedron Lett., 4329 (1973).

22. G. Wulff, Angew. Chem. Int. Ed. Engl., 34, 1812 (1995).

23. S. A. Piletskii, I. Y. Dubei, D. M. Fedoryak, and V. P. Kukhar, Biopolim. Kletka, 6, 55 (1990).

24. M. Yoshikawa, J. Izumi, T. Kitao, S. Koya, and S. Sakamoto, J. Membrane Sci., 108, 171 (1995).

25. M. Yoshikawa, J. Izumi, and T. Kitao, Chem. Lett., 611 (1996).

26. J. A. Riddick, W. B. Bunger, and T. K. Sakano, "Organic Solvents," 4th ed, Wiley, New York, N.Y., 1986.

27. D. P. Perrin and W. L. F. Armarego, "Purification of Laboratory Chemicals," 3rd ed, Pergamon Press, Oxford, 1988.

28. R. B. Merrifield, J. Am. Chem. Soc., 85, 2149 (1963).

29. R. B. Merrifield, Angew. Chem. Int. Ed. Engl., 24, 799 (1985).

30. B. F. Gisin, Helv. Chim. Acta, 56, 1476 (1973).

31. R. B. Merrifield, L. D. Vizioli, and H. G. Boman, Biochemistry, 21, 5020 (1982)

32. D. Yamashiro and C. H. Li, Proc. Natl. Acad. Sci. U.S.A., 71, 4945 (1974).

33. E. Kaiser, R. L. Colescott, C. D. Bossinger, and P. I. Cook, Anal. Biochem., 34, 595 (1970).

34. R. F. Ebert, Anal. Biochem., 154, 431 (1986).

35. R. Knecht and J.-Y. Chang, Anal. Chem., 58, 2375 (1986).

36. D. Voet and J. G. Voet, "Biochemistry," Wiley, New York, N.Y., 1990.

37. C. Tanford, J. Am. Chem. Soc., 84, 4240 (1962).

38. Y. Nozaki and C. Tanford, J. Biol. Chem., 246, 2211 (1971).

39. J.-L. Fauchère and V. Pliska, Eur. J. Med. Chem.-Chim. Ther., 18 , 369 (1983).

40. C.-C. Chen, Y. Zhu, J. A. King, and L. B. Evans, Biopolymers, 32, 1375 (1992) 